CLINICAL STUDY

\title{
Age- and gender-dependent urinary iodine concentrations in an area-covering population sample from the Bernese region in Switzerland
}

\author{
Claudine Als ${ }^{1,2,5}$, Alain Keller ${ }^{1}$, Christoph Minder ${ }^{3}$, Max Haldimann ${ }^{4}$ and Hans Gerber ${ }^{1}$ \\ ${ }^{1}$ Department of Clinical Chemistry, Inselspital, University of Bern, CH-3010 Bern, Switzerland, ${ }^{2}$ Institute of Pathology, University of Bern, CH-3010 \\ Bern, Switzerland, ${ }^{3}$ Institute of Social and Preventive Medicine, University of Bern, CH-3012 Bern, Switzerland, ${ }^{4}$ Swiss Federal Office of Public Health, \\ CH-3003 Bern, Switzerland and ${ }^{5}$ Department of Nuclear Medicine, Clinique Ste Thérèse, L-2763 Luxembourg, Luxembourg \\ (Correspondence should be addressed to C Als, Email: claudine.als@insel.ch)
}

\begin{abstract}
Objective: Before a scheduled increase of salt iodide content up to 20 p.p.m. in Switzerland, urinary iodine concentration (UIC, $\mu \mathrm{g} / \mathrm{l}$ ) of a randomly selected, area-covering, age-stratified population subgroup was sampled in spring 1997. In contrast to former published studies on UIC, we minimized biases by age, gender, rural/urban, socio-economic and cultural influences.

Methods: We contacted 750 households in the Bernese region using random telephone numbers. Per household, one proband selected by play dice collected a spot urine sample. We defined seven age categories: infants, children, adolescents, adults I-III and seniors, aged 0-5, 6-12, 13-20, 21-35, 36-50, 51-65 and >65 years respectively. Randomized UIC data were compared with WHO criteria of iodine deficiency (ID) and previous non-randomized, age-dependent Swiss UIC data. To recruit a perfect random group of volunteers proved difficult, as study participation of adolescent and male populations was somewhat lower than that of elder and female $(P<0.005)$ populations respectively. Study participation of inhabitants of rural and suburban regions was comparable $(P=0.139)$. Out of 413 obtained urine spots, $412(55 \%)$ were analyzed statistically $(58 \%$ women, $42 \%$ men, $P<0.005)$.

Results: Ninety per cent of all UIC values ranged between 25 and $200 \mu \mathrm{g} / \mathrm{l}$. Median UIC showed mild ID $(94 \mu \mathrm{g} / \mathrm{l})$. UIC varied significantly between age categories $(P=0.0006)$. Women had lower UIC than men $(P=0.014)$. Infants had no ID. Women in child-bearing age (13-35 years), adults II, adults III and seniors had mild ID. Compared with recommended supplies of 150 and $200 \mu \mathrm{g}$ I/day in children and male adolescents respectively, we consider their UIC (110 and $144 \mu \mathrm{g} / \mathrm{l})$ as at least borderline deficient. Absolute UIC was lowest in seniors. Probands from rural/suburban households had similar UICs. Our UIC data were comparable to published ones.

Conclusions: Despite long-term national efforts with iodized salt (15 p.p.m. in 1997), mild ID still prevailed in Bern in spring 1997, with rare extreme UIC values. Mild ID with women in child-bearing age (and probably also with children and male adolescents) was a serious concern, as goiter growth with puberty or pregnancy might be the consequence. Mild ID in adults and seniors might be due to restricted $\mathrm{NaCl}$ intake. Results of our randomly selected subgroup from a 650000 population show that age- and gender-dependency are important when comparing our collected data with published UIC data. This fact must be considered with non-randomly selected population subgroups.
\end{abstract}

European Journal of Endocrinology 143 629-637

\section{Introduction}

In Switzerland, severe iodine deficiency (ID) had progressively resolved with increasing salt iodide contents of $3.75,7.5$ and 15 p.p.m., introduced in 1922, 1962 and 1980 respectively $(1,2)$. Due to State monopoly of salt production and trade coupled with legally fixed and identical prices for all sorts of salt, iodized salt reaches large parts of the population (3).
Urinary iodine progressively increased, with mean urinary iodine concentration (UIC) of $18 \mu \mathrm{g} \mathrm{I} / \mathrm{l}$ severe ID - in 1921 (4) to 66 and $87 \mu \mathrm{g} \mathrm{I/g}$ creatinine - mild ID - in 1975 and 1991 respectively (2). As a consequence, the frequency of goiter (volume of thyroid gland $>25 \mathrm{~g}$ ) in autopsy series from Zurich decreased; most promptly in children and young adults, with more delay in elder patients $(5,6)$. In women aged $41-50$ years, for instance, goiter frequency decreased from 


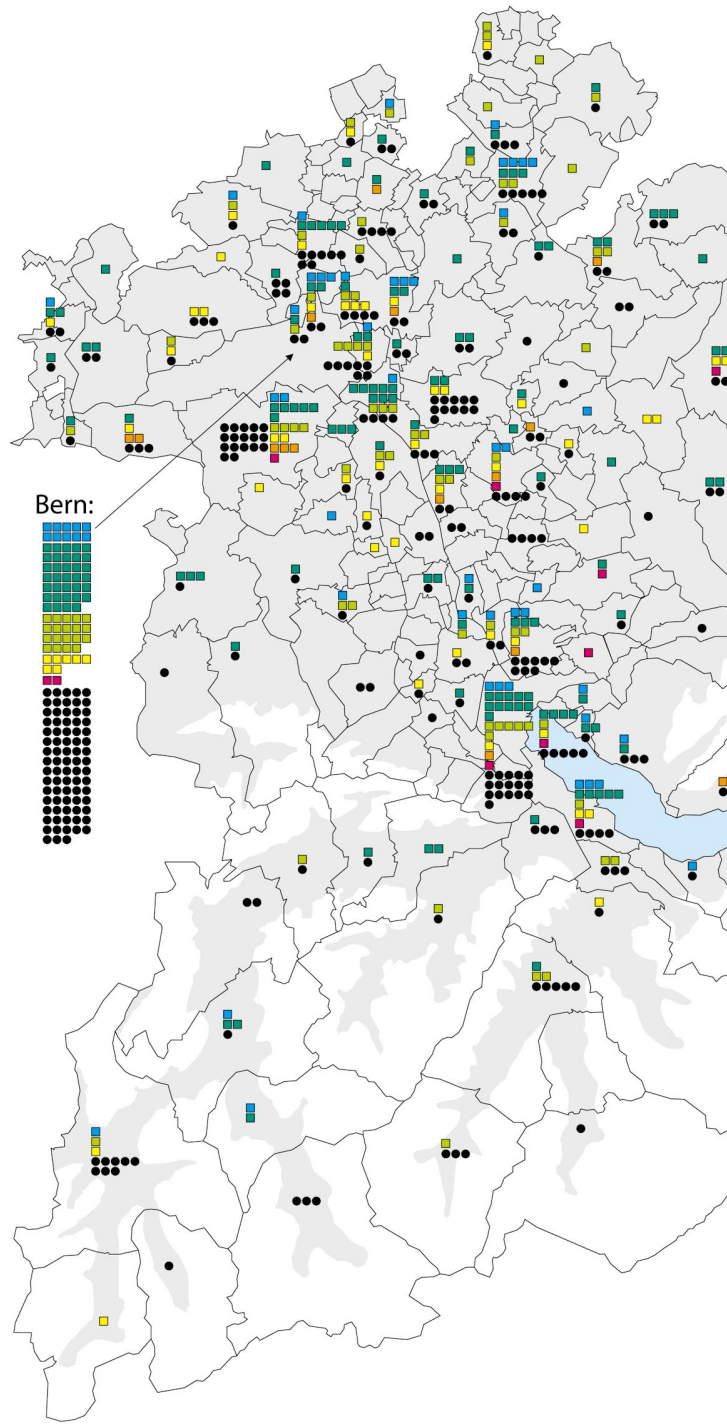

1b) population density 1997 : inhabitants per $\mathrm{km}^{2}$

$$
\begin{array}{r}
\square \quad 0-49 \\
\square \quad 50-99 \\
\square 100-149 \\
\square 150-299 \\
\square 300-499
\end{array}
$$

settled population

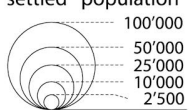

Design: Egli H.-R., Cartography: Brodbeck A.

(C) Institute of Geography, University of Bern, CH-3012 Bern, 1999

1a) distribution of UIC data

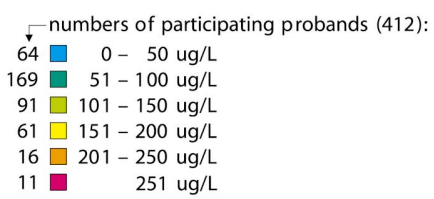

- non-participants (338)

$\square$ Territory below $1400 \mathrm{~m}$ above sea level (productive surface and settlement territory) 
Table 1 Description of the seven age categories; age-dependent proportions of participating probands compared with the general population of the Bernese region in 1997.

\begin{tabular}{|c|c|c|c|c|c|c|c|c|c|c|c|c|c|c|c|c|}
\hline & \multicolumn{14}{|c|}{ Age categories, age span (years) } & & \\
\hline & \multicolumn{2}{|c|}{$\begin{array}{c}\text { Infants } \\
0-5\end{array}$} & \multicolumn{2}{|c|}{$\begin{array}{l}\text { Children } \\
6-12\end{array}$} & \multicolumn{2}{|c|}{$\begin{array}{c}\text { Adolescents } \\
13-20\end{array}$} & \multicolumn{2}{|c|}{$\begin{array}{l}\text { Adults I } \\
21-35\end{array}$} & \multicolumn{2}{|c|}{$\begin{array}{l}\text { Adults II } \\
36-50\end{array}$} & \multicolumn{2}{|c|}{$\begin{array}{l}\text { Adults III } \\
51-65\end{array}$} & \multicolumn{2}{|c|}{$\begin{array}{l}\text { Seniors } \\
>65\end{array}$} & \multicolumn{2}{|c|}{ Total } \\
\hline & $n$ & $\%$ & $n$ & $\%$ & $n$ & $\%$ & $n$ & $\%$ & $n$ & $\%$ & $n$ & $\%$ & $n$ & $\%$ & $n$ & $\%$ \\
\hline Urine spots & 31 & 7.5 & 47 & 11.6 & 24 & 5.8 & 44 & 10.7 & 72 & 17.4 & 109 & 26.4 & 85 & 20.6 & 412 & 100 \\
\hline Men & 14 & & 19 & & 11 & & 13 & & 37 & & 41 & & 38 & & 173 & 42 \\
\hline Women & 17 & & 28 & & 13 & & 31 & & 35 & & 68 & & 47 & & 239 & 58 \\
\hline $\begin{array}{l}\text { General population } \\
\qquad(n \times 1000)\end{array}$ & 62 & 6.6 & 76 & 8.1 & 74 & 7.9 & 196 & 20.9 & 211 & 22.5 & 163 & 17.3 & 157 & 16.7 & 940 & 100 \\
\hline
\end{tabular}

$88 \%$ in 1949 to $26 \%$ in 1979 and to $18 \%$ in 1984 (5, 6). Although in 1997 goiter frequency in school children was found to be low (7), the question remains whether, despite the national efforts undertaken, the Swiss problem of iodine deficiency disorders (IDD) is fully resolved in all age groups and, within age groups, as well with women as with men.

As $1.5 \times 10^{9}$ or about $20 \%$ of the world's population are at risk for IDD, eradication of $\mathrm{ID}$ is a primary goal worldwide. However, proband groups in virtually all studies on urinary iodine concentration (UIC) underlie several selection biases $(7-12)$. Due to the "probability proportionate to size' sampling method, rural populations are liable to be underrepresented as compared with urban ones (lower versus higher population densities). Diet in rural and urban regions might be different, depending more on consumption of own salted meat products with a high lipid content in rural areas, compared with more industrially prepared, 'light' food products from retail stores in urban areas. UIC from rural or urban regions might therefore be different as well. Studied population subgroups are mostly school children, community workers, hospitalized patients, outpatients in a doctor's ward such as pregnant women, or friends and relatives of the authors. In spite of biases due to the restricted geographic origin of such subgroups and the non-uniform representation of age groups, genders, cultural and socio-economic conditions, those studies are nevertheless commonly interpreted as generating representative data of overall populations. We wondered about the relevance of such biases.

In the present paper, our aim therefore was to evaluate UIC in a well-defined geographical area of the Bernese region in Switzerland, looking at randomly selected subjects in all age-groups, using standard analytical and statistical methodology accepted for epidemiological studies. The following questions were asked: Do age and gender significantly influence UIC? Are certain age groups more at risk of IDD than others? Do randomly selected, age-stratified data differ from those of non-randomly selected groups of published Swiss studies? What is the impact of a rural versus an urban population subgroup on study findings?

\section{Materials and methods}

\section{Proband selection by random telephone numbers and play dice-data collection}

As UIC had repeatedly been demonstrated to fluctuate (1, 2, 13-16), salt iodide content in Switzerland was increased from 15 to 20 p.p.m. in September 1998, after termination of the present study. Before this scheduled change, our aim was to present one-time urinary iodine data of responders of a randomly selected, representative sample of the Bernese population, aged 090 years. Due to randomness, the selection included persons dwelling in both urban and rural communities, minimizing biases due to age, gender, socio-economic and cultural influences. The ethical commission of the University of Bern had approved the study design (number 32-49424.96) patronized by the Swiss National Foundation for Scientific Research. In order not to influence proband selection, no financial reward was offered. Complete sample collection was conducted from 21 March to 6 May 1997.

In 1997, the investigated population of the Bernese region within a $4500 \mathrm{~km}^{2}$ territory counted 650000 persons. The national telephone company - then still a monopoly with $93 \%$ of the population accessible by telephone - provided a random sample of $n=750$ private telephone numbers, representing a major part of the $4500 \mathrm{~km}^{2}$ region (Fig. 1) $(17,18)$. More probands and non-participants came from the densely populated communes; representation of the 750 telephone numbers was thus proportionate to population density. Even remote mountain valleys in the south with a low population density were represented. An official letter with information about the study was sent to all 750 households. Thereafter, a single person within each household was selected by throwing a play dice during a telephone conversation: a random method. We aimed for about 400 urine spots and a minimum of 30 persons per age category. To generate data in comparison with past and future epidemiologic studies, seven age categories were prospectively defined according to pre-, primary and secondary school 
periods up to 20 years of age (infants, children and adolescents) and 15-year periods thereafter (adults IIII and seniors). Age spans in categories infants, children, adolescents, adults I-III and seniors were $0-5,6-12,13-20,21-35,36-50,51-65$ and $>65$ years respectively.

We effectively obtained $491(65.5 \%)$ oral consents and $413(55 \%)$ returned urine tubes $(84.1 \%$ of the consents, Table 1). One mother aged 34 years (category adults I) had filled the urine tube in error, instead of her play-dice-selected daughter aged 9 years (category children), so the corresponding urine tube was rejected from statistical analysis. The definitive number of 'participants' or of urine tubes was therefore 412 (100\%). Compared with prevalence of both sexes in the general population (women 51\%), study participation of women $(n=239,58 \%)$ was significantly higher than that of men $(n=173,42 \%, P<0.005)$, especially in categories adults I to seniors. In all age categories except in adolescents, the minimally expected number of 30 probands could be obtained. The adolescents category had only 24 probands despite a second and third letter of encouragement that was not answered in 12 out of 15 cases. In age categories adults I to seniors, in accordance with the population's age structure, we had no problem in reaching sufficient proband numbers. Regional distribution of participating probands and of general population were roughly similar. Adolescents and adults I and II were slightly underrepresented, whereas there was a tendency to overrepresentation of adults III and seniors. Reasons for non-participation in $259(34.5 \%)$ cases were: no interest or no time $(n=93)$; too complicated in regard of old age $(n=76)$; no answer after seven telephone calls $(n=55)$; inadequate phone number, or phone number belonging to a holiday home, etc. $(n=35)$. The total number of non-participants was $n=338$ (45\%). Refusal rates between rural and urban regions were not significantly different $(P=0.139)$.

Recruitment by random selection of our proband group aged 0-90 years, representative of an area covering $4500 \mathrm{~km}^{2}$ with 650000 inhabitants (Fig. 1) is in marked contrast to previous studies on UIC, in which, for practical reasons, only one or two age categories were usually represented and proband selection did not address the issue of sample biases. Apart from the drop-outs, the present sample is random. We see no way of improving randomness of the sample under conditions of voluntary participation, as refusers make it very difficult or impossible to constitute a truly representative age-stratified and areacovering proband group. There are small biases caused by refusers. Indeed, possibly because of personal reasons, little interest in health questions and lack of motivation respectively, pregnant women, adolescents (2) and males (19) were somewhat underrepresented. To obtain sufficient numbers of infants, children and adolescents, we excluded adults from play-dice selection in households with 0 to 20-year-olds after 15 April 1997. Therefore, 'parents' might be somewhat underrepresented compared with childless singles (adults I), whose possibly different diet could represent a bias. Recent evidence of a circadian rhythm of UIC (20) moreover points to the fact that a bias exists with sampling hour, which was not recorded by our probands as this knowledge was not yet available when planning the present study.

\section{Laboratory analyses}

Urine tubes were immediately frozen at $-30^{\circ} \mathrm{C}$. UIC was determined by the Sandell-Kolthoff method adapted to modern laboratory equipment (21) by a well trained technical staff that had also performed the analyses of previous Swiss studies $(1,2,13-16,21$, 22). The coefficient of variation of the iodine assays was $7.5 \%$ (within-run precision). All chemical reagents were purchased from Merck (Bern, Switzerland). Oxidation of the iodine calibrators and urine samples was performed manually in single glass tubes in a block heater. Urine samples $(0.4 \mathrm{ml})$ and $\mathrm{KIO}_{3}$ calibrators $(0.4 \mathrm{ml})$ ranging from 0 to $3 \mu \mathrm{mol} / \mathrm{l}$ were added to $0.25 \mathrm{ml}$ of a mixture (1:4 by volume) of $\mathrm{HNO}_{3}(65 \%)$ and $\mathrm{HClO}_{4}(70 \%)$ and digested in the block heater at a nominal temperature of $225^{\circ} \mathrm{C}$ for $25 \mathrm{~min}$. After the solution had cooled, $2 \mathrm{ml}$ of water were added, and the solution was shaken; $100 \mu \mathrm{l}$ of this solution were then pipetted directly into 96-well microwell plates. A $100 \mu \mathrm{l}$ volume of $\mathrm{As}_{2} \mathrm{O}_{3}$ solution (final As concentration: $40 \mathrm{mmol} / \mathrm{l})$ and $50 \mu \mathrm{l}$ of $\left(\mathrm{NH}_{4}\right)_{4} \mathrm{Ce}\left(\mathrm{SO}_{4}\right)_{3}$ solution (final Ce concentration: $6.4 \mathrm{mmol} / \mathrm{l}$ ) were added to each well. Iodine calibrators were measured with each microplate. Absorption was measured after a reaction time of $30 \mathrm{~min}$ by an automatic microwell-plate reader (SLT-Labinstruments spectrophotometer) at $405 \mathrm{~nm}$. Three replicates of each sample were analyzed consecutively $(21,22)$.

\section{Calculations and statistics}

UIC data were expressed as I/volume $(\mu \mathrm{g} \mathrm{I} / \mathrm{l})$ as recommended (18). As results expressed as I/volume might not be comparable with those expressed as I/ creatinine, the latter were not comparatively shown in order to avoid confusion (C Als, C Minder, D Willems, H V Van Thi, H Gerber \& P Bourdoux, unpublished observations, 23). In search of potential differences of UIC data from rural/suburban households, visual semiquantitative cartographic figures of the regional distribution of UIC were designed at the Geographical Institute of the University of Bern. Medians and ranges (means not shown) as well as percentages were used to describe the sample as well as levels and variabilities of UIC (in $\mu \mathrm{g} / \mathrm{l}$ ) by age and gender. UIC was correlated with weight (in $\mathrm{kg}$ ) and body mass index in women and men. Chi square test was used to compare participation 


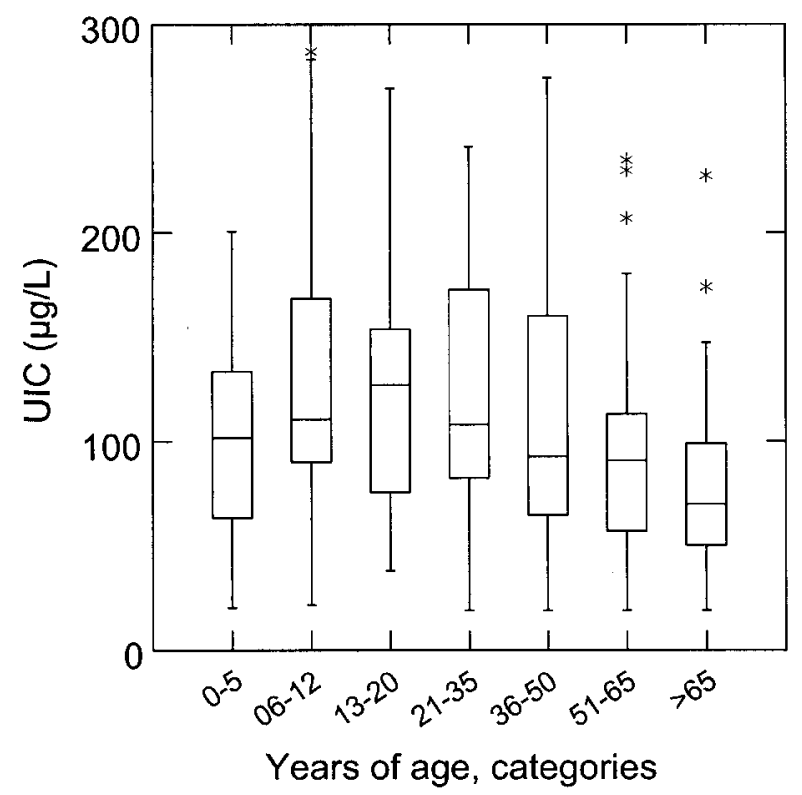

Figure 2 Box plot representation of urinary iodine concentration (in $\mu \mathrm{g} \mathrm{l} / \mathrm{l}$ ) data according to age groups. The length of each box shows the range within which the central $50 \%$ of the values fall. In a box, the central horizontal line marks the median value. Vertical lines above and below the box cover a range of 1.5 times the length of the box. $*$, outliers.

frequencies of women versus men, of inhabitants from rural versus urban/suburban regions and numeric results between age categories (heterogeneity). The Mann-Whitney test was used to compare genderdependent UIC data.

To assess whether UIC data were indicative of ID or not and following WHO recommendations (WHO/NUT 94.6), percentages of UIC results found below ageunrelated thresholds were calculated: $>0.79 \mu \mathrm{mol} \mathrm{I} / \mathrm{l}$ or $>100 \mu \mathrm{g} \mathrm{I} / \mathrm{l}$ (corresponding to no ID); $<0.79 \mu \mathrm{mol}$ I/l or $<100 \mu \mathrm{g} \mathrm{I} / \mathrm{l}$ (corresponding to mild ID); $<0.39 \mu \mathrm{mol} \mathrm{I} / \mathrm{l}$ or $<50 \mu \mathrm{g} \mathrm{I} / \mathrm{l}$ (corresponding to moderate ID); and $<0.20 \mu \mathrm{mol} \mathrm{I} / \mathrm{l}$ or $<25 \mu \mathrm{g} \mathrm{I} / \mathrm{l}$ (corresponding to severe ID).

Indicator of ID 'elimination' thus is a median value for UIC of $100 \mu \mathrm{g} \mathrm{I} / \mathrm{l}$, i.e. $50 \%$ of samples should be $>100 \mu \mathrm{g} \mathrm{I} / \mathrm{l}$ and not more than $20 \%$ of samples should be $<50 \mu \mathrm{g} \mathrm{I} / \mathrm{l}$. Those WHO criteria consider the fact that UIC data in spot urine samples - as in the present study - underestimate true urinary iodine excretion as given by urine collections of $24 \mathrm{~h}$ (C Als, C Minder, D Willems, H V Van Thi, H Gerber \& P Bourdoux, unpublished observations, 23). As WHO criteria are, however, not age-related, we moreover considered, as a secondary indicator of ID, age-related criteria of iodine supply (in $\mu \mathrm{g} \mathrm{I} /$ day). Daily nutrition should ideally provide $150 \mu \mathrm{g}$ iodine in adults, $200 \mu \mathrm{g}$ in adolescents, pregnant or lactating women, $90 \mu \mathrm{g}$ in infants and children up to 6 years and $120 \mu \mathrm{g}$ in children aged 6-10 years (24). The latter criteria of ID based on agerelated iodine supply will be discussed below only in case of discordancy with WHO criteria.

\section{Results}

\section{Data distribution}

Few out of the 412 samples had extreme values of UIC: only $11(3 \%)$ single values were found $<25 \mu \mathrm{g} \mathrm{I} / \mathrm{l}$. Only three $(1 \%)$ single UIC values were found $>500 \mu \mathrm{g}$ $\mathrm{I} / \mathrm{l}(699 \mu \mathrm{g} / \mathrm{l}$ linked to polyvidone-iodine disinfection, and $5791 \mu \mathrm{g} / \mathrm{l}$ and $5457 \mu \mathrm{g} / \mathrm{l}$, both linked to amiodarone intake). Due to the right-skewed data distribution, median UIC data gave a more pessimistic, albeit more realistic impression than did mean values (data not shown).

\section{Pooled UIC data (Table 2, Fig. 2)}

The median UIC of all 412 random urine samples was found to be below $100 \mu \mathrm{g} / \mathrm{l}: 94 \mu \mathrm{g} / \mathrm{l}$. Out of the 412 pooled samples, only $88(22 \%)$ were found to be $>150 \mu \mathrm{g} \mathrm{I} / \mathrm{l}$, and only 184 (44\%) had values $>100 \mu \mathrm{g}$ $\mathrm{I} / \mathrm{l}$, whereas as much as $16 \%$ had values $<50 \mu \mathrm{g} \mathrm{I} / \mathrm{l}$. WHO criteria thus indicated mild ID.

Table 2 Age- and sex-dependent median UIC data ( $\mu$ g I/I). Criteria in favor of 'elimination' of ID: (1) age-independent UIC ( $\mu$ I I/I): median values should be $100 \mu \mathrm{g} \mathrm{I} / \mathrm{I}$ (bold numbers indicate ID), $>50 \%$ of samples should be $>100 \mu \mathrm{g} \mathrm{I/I}$ and $<20 \%$ of samples should be $<50 \mu \mathrm{g}$ $\mathrm{I} / \mathrm{I}$ (WHO recommendations) and, as a secondary approximation: (2) age-dependent daily iodine supply ( $\mu \mathrm{g} \mathrm{l} / \mathrm{day})(24)$.

\begin{tabular}{|c|c|c|c|c|c|c|c|c|c|}
\hline & & \multicolumn{7}{|c|}{ Age categories } & \multirow[b]{2}{*}{ All ages } \\
\hline & & Infants & Children & Adolescents & Adults I & Adults II & Adults III & $\overline{\text { Seniors }}$ & \\
\hline \multirow[t]{3}{*}{ All } & Median UIC ( $\mu \mathrm{g} \mathrm{I/I)}$ & 108 & 110 & 127 & 110 & 93 & 91 & 71 & 94 \\
\hline & $\%$ samples $>100 \mu \mathrm{g} \mathrm{I} / \mathrm{l}$ & 59 & 60 & 66 & 59 & 42 & 39 & 24 & 44 \\
\hline & $\%$ samples $<50 \mu \mathrm{g} \mathrm{l} / /$ & 9 & 8 & 13 & 4 & 19 & 17 & 27 & 16 \\
\hline Women & Median UIC ( $\mu \mathrm{g} \mathrm{I/I})$ & 105 & 111 & 90 & 91 & 93 & 84 & 70 & 90 \\
\hline \multirow[t]{3}{*}{ Men } & Median UIC ( $\mu \mathrm{g} \mathrm{I/I})$ & 110 & 108 & 144 & 169 & 98 & 98 & 83 & 104 \\
\hline & Recommended UIC (WHO) & 100 & 100 & 100 & 100 & 100 & 100 & 100 & 100 \\
\hline & $\begin{array}{l}\text { Recommended age-related } \\
\text { iodine supply ( } \mu \mathrm{g} / \text { day })\end{array}$ & 90 & $90-150$ & 200 & 150 & 150 & 150 & 150 & 150 \\
\hline
\end{tabular}




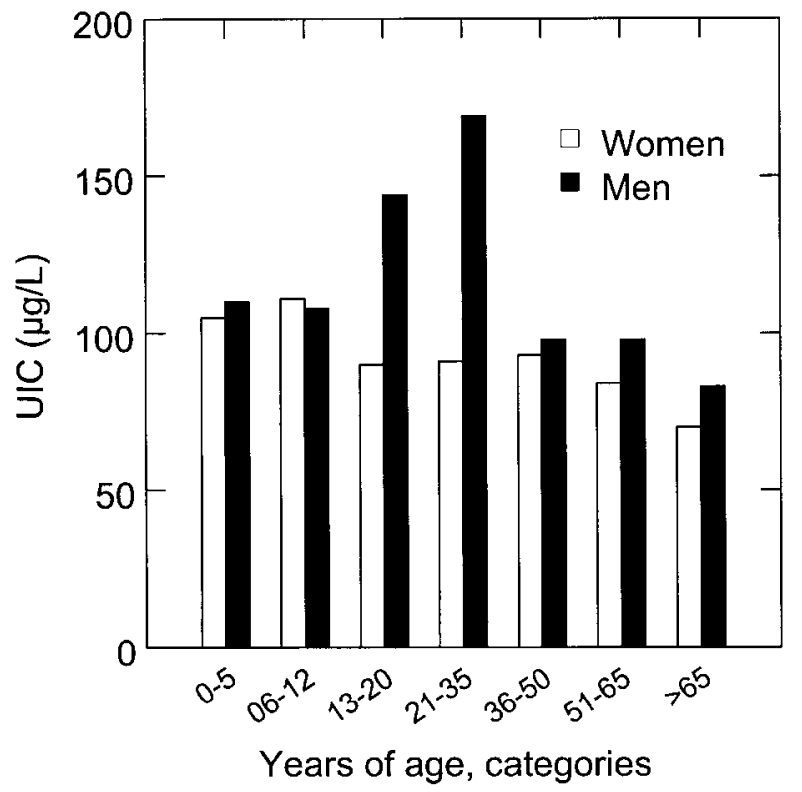

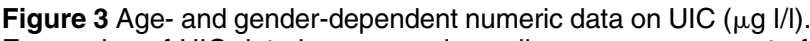
Expression of UIC data by mean values allows an assessment of the average UIC of the population.

\section{Age-related UIC data (Table 2, Fig. 2)}

Infants, children, adolescents and adults I were found not to be iodine-deficient, as well as concerned median values as the percentage found below thresholds recommended by WHO. However, adults II and III and seniors were found to be iodine-deficient, as well with median values as with the percentage found below WHO thresholds (as explained in section on 'Calculations and statistics'). Median UIC decreased with age from adolescents to adults I-III and was found lowest in seniors. Percentages of UIC data (cell frequencies) found to be below thresholds of iodine supply defined by steps of $25 \mu \mathrm{g}$ were significantly different (using the $\chi^{2}$ test) in the seven age categories: $P=0.0006$ (all data) or $P=0.00005$ (if the few data above the threshold $200 \mu \mathrm{g} \mathrm{I} /$ day were excluded; they were epidemiologically irrelevant because they were so few).

As far as age-related criteria of iodine supply were concerned (24), and as opposed to WHO criteria, median UIC has however to be considered borderline with children and adolescents. Median UIC of adolescents and children was found most remote from their recommended thresholds of 200 and $150 \mu \mathrm{g}$ I/day respectively. Adolescents reached their recommended threshold of $>200 \mu \mathrm{g} \mathrm{I} /$ day in only $13 \%$ of cases.

\section{Gender-related UIC data (Table 2, Fig. 3)}

Pooled data of all 239 female probands showed mild ID, whereas pooled data of all 173 male probands sharply indicated absent ID (Fig. 3). Women had significantly lower UIC values than men $(P=0.014)$; this was most prominent in adolescents and adults I. Thus, girls and women of child-bearing age (aged 13-35 years) had the most unsatisfactory results. Male adolescents, with a $60 \%$ higher median UIC than females, had a WHOsufficient UIC. In young adults I, aged 21-35 years, UIC was WHO-sufficient in men, but showed mild ID in women. In the other age categories, gender-dependent results were comparable with those of the pooled data of both sexes per age category: sufficient UIC in infants and children, mild ID in adults II, adults III and seniors. UIC data did not correlate with weight $(r=0.018)$ or body mass index $(r=0.147)$.

As far as age-related criteria of iodine supply were concerned (24), and in contrast to WHO criteria, both male and female children and adolescents are to be considered to have mild ID.

\section{UIC in rural and suburban settings (Fig. 1)}

In Fig. 1 b, population density per $\mathrm{km}^{2}$ in each district is indicated by a color scale. The most densely populated, (sub)urban, districts are differentiated from rather rural districts with a low population density. Together with Fig. 1a, semi-quantitative visual comparison of UIC data from (sub)urban and rural regions shows a slight difference, as distribution of the six UIC color spots seems heterogeneous: no orange or red spots are found in southern mountain rural regions. The difference can, however, not be considered significant.

\section{Discussion}

Despite long-term national efforts to control and eradicate IDD with iodized salt in Switzerland, UIC was found to be $<100 \mu \mathrm{g} \mathrm{I} / \mathrm{l}$ in as much as $56 \%$ of 412 urine samples, collected randomly in the Bernese region in spring 1997, thereby indicating mild ID. These results confirm previous Swiss findings on mild ID in the 1990s $(1,2,13-16)$. It is interesting that in the Bernese population, in which the iodine supply depends mainly on iodized salt, UIC data were less widely spread than in populations with excess iodine supply, depending on sources other than iodized salt, such as seaweed (9). Thus, $90 \%$ of all values were found within the range 25-200 $\mu \mathrm{g} \mathrm{I/l}$. The rare extreme values are not epidemiologically relevant. Extremely high values in Bern (UIC $>500 \mu \mathrm{g}$ I/l) were linked to alternative sources of iodine, such as recent large polyvidone disinfection or chronic amiodarone intake. Rare very low values $(<25 \mu \mathrm{g} / / \mathrm{l})$ simply mirror a known high intra-individual variability with UIC $(2,13,23,25)$. Another argument against too much pessimism with some very low UIC values is the fact that goiter frequency in school children from Lausanne and Solothurn was concomitantly found to be low, i.e. $<3 \%$ (7). Of course, goiter frequency in adults, with an iodine-deficient regimen during childhood, was higher (6). 
There could be two reasons why the UIC of the pooled data was found to be unsatisfactory despite salt iodization (15 p.p.m. in spring 1997). If urine spots had been sampled over a year, the UIC results might have been different. A possible influence of collecting data in spring is suspected, as low and high iodine contents in summer versus winter milk respectively have been described in Switzerland and in Great Britain $(26,27)$. A second cause is to be found in modified eating habits (2). As alimentation in an affluent society depends more and more on industrially manufactured foodstuffs prepared with uniodized or half-iodized salt (7.5 p.p.m.), 15 p.p.m. salt did most probably not sufficiently reach the consumer. Thus, for instance, iodide content was found to be very low in industrially prepared, salted Swiss potato chips, indicating that the manufacturer had not used iodized salt (manuscript in preparation). Moreover, as salt individually added to foodstuffs in the kitchen or at table accounts for only 2-3 g/day, individual consumers have little opportunity to influence iodine supply by means of iodized salt consumption (2). Salt iodide content in Switzerland was therefore increased up to 20 p.p.m. in September 1998, after terminating data collection of the present study.

The study showed a highly significant age- and gender-dependent UIC difference. Of concern were our significantly undersupplied female probands aged 1335 years (adolescents and adults I) in the reproductive age (mild ID). Adolescent girls, as well as young women, might become pregnant in the following years. It is true that pregnant women in Switzerland have been reported to have a sufficient iodine supply thanks to artificial supplementation $(14,16)$. However, as during the first few weeks of pregnancy and before its diagnosis, the probability of ID is high (28), and as the aim of therapeutic intervention is to avoid hypothyroxinemia and goitrogenesis in both mother and newborn, iodine supplementation should be initiated as soon as possible (29). Furthermore, and besides considerations on pregnancy, mild ID of female adolescents and borderline insufficiency of children and male adolescents were a serious concern. Requirements of iodine intake related to thyroid hormone synthetic rates depend on age and physiological conditions and are particularly high in adolescents: $200 \mu \mathrm{g} /$ day. Inadequacy of iodine intake is probably most prominent in adolescents, who are at risk of developing delayed IDD, as sensitivity to ID of thyroid gland metabolism is enhanced during sexual maturation. This fact is illustrated by observation of goiter growth after puberty in adolescents of an iodinedeficient area against absence of goiter growth after puberty in an iodine-sufficient area in the Tuscan Apennines in Italy (30). With regard to adults II, adults III and seniors, occasional goiter growth with some derived complications could find an explanation in our findings of mild ID (31-35), that might be caused by decreased iodine intake with alimentary salt restriction. As diuresis is moreover reduced in the elderly, causing higher levels of UIC, the lowest UIC of all groups found in seniors cannot be an artifact. The question of whether deficient UIC in adolescents and seniors is a true age effect or a cohort effect should be resolved by further longitudinal studies. Gender dependency of UIC in Switzerland has been described previously (36). No correlation was, however, found between UIC and weight or body mass index. Do males (with a higher body weight) and females (with a lower body weight) in analogy to different proteo-caloric intakes (37) also have different iodine intakes? Do females, for cultural reasons, have qualitatively different diets than males? Do males, and especially male adolescents, because of increased perspiration with a higher physical activity, have an artificially increased UIC due to a lesser urinary volume? Further studies should clarify these points.

Comparison of data from rural versus urban population subgroups led to no demonstrable impact on compliance rate and UIC values. Further studies on UIC in industrialized countries need therefore not to consider rural or suburban provenance of probands as a bias. The situation might, however, be different in developing countries.

We compared our randomly selected, age-dependent UIC data (expressed as $\mu \mathrm{g} \mathrm{I} / \mathrm{l}$ ) with those from nonrandomly selected Swiss population subgroups investigated after 1980 , i.e. after salt iodide concentration had increased from 7.5 to 15 p.p.m. With our data, as with literature data, no age group had a sufficient UIC, except infants and children. With infants, the only literature study in fact concerned neonates (with a sufficient mean UIC of $66 \pm 33 \mu \mathrm{g} \mathrm{I} / \mathrm{l})$, who were younger than our 'infants' aged $0-5$ years (14). Literature results of mean UIC concerning children were found at similar or at higher levels $(117 \pm 58 \mu \mathrm{g}$ I/l to $161 \pm 63 \mu \mathrm{g} \mathrm{I} / \mathrm{l})$ than in our randomly selected population (20), but most of the studied groups originated from our Bernese region $(7,38)$. The highest children's values were found in Lausanne and Solothurn, where iodine supply might be higher than in Bern (7). The Lausanne region indeed has a different salt provider than the rest of the Swiss territory and Solothurn is located on the border of the Jura Mountains, where no endemic goiter and no severe ID have ever prevailed (4). It is therefore uncertain whether the relatively high UIC data from Lausanne and Solothurn can be considered representative of the whole Swiss territory. A possible reason why only one group of adolescents is represented in the literature, with mean $\mathrm{UIC}=100 \pm 47 \mu \mathrm{g} \mathrm{I} / \mathrm{l}$, is that authors might shrink from the compliance problems that we encountered in the present study (39). With adults I to adults III, literature data indicated mean UIC from $66 \pm 33 \mu \mathrm{g} \mathrm{I} / \mathrm{l}$ to $108 \pm 17 \mu \mathrm{g} \mathrm{I} / \mathrm{l}(1,2,13,16,40)$. No 'official' senior age group has been published, but a 
very small senior group could be 'extracted' out of a larger pool of adult volunteers: mean $\mathrm{UIC}=77 \pm$ $19 \mu \mathrm{g} \mathrm{I} / \mathrm{l}$ (2). Thus, our age-dependent randomized UIC results and the non-randomized UIC data from the literature were found to be similar. Comparison of UIC data from randomized with non-randomized subject groups therefore leads to no evidence that randomness is indispensable, provided age- and moreover genderdependencies are observed. However, despite small inevitable biases cited above, evaluation of UIC in a representative population subgroup stratified by age and gender offers highly interesting information on iodine supply that had, to our knowledge, not been shown before.

In conclusion, our attempt to assemble by random telephone numbers and play dice throwing an areacovering, age-stratified proband population, representative in spring 1997 of part of the Bernese territory with 650000 inhabitants showed that UIC, measured as $\mu \mathrm{g} \mathrm{I} / \mathrm{l}$, was mildly deficient in subjects aged 0-90 years, and was of most concern in female probands aged 13-35 years of child-bearing age. Children and male adolescents probably have a borderline mild ID. Infants had a better iodine supply, possibly related to milk intake. In adults, UIC decreased with age, possibly as a consequence of restricted $\mathrm{NaCl}$ intake. Sampling of spot and not of $24 \mathrm{~h}$ urine, in spring and not in winter, might in part explain the low UIC values. Without being dramatic, the situation is not satisfactory. In a country that has played a pioneering role in introducing salt iodization as early as the 1920s, vulnerable, age-dependent subgroups of the population still suffer from mild to moderate ID.

\section{Acknowledgements}

This work was supported by grants from the University Hospital in Bern, the 'Swiss National Foundation for Scientific Research', the 'Fondation Genevoise de Bienfaisance V. Rossi di Montelera', the 'Schweizerische Rentenanstalt' and the 'Schüpbach Foundation'. We thank P D Dr Hans-Rudolf Egli and Mr A Brodbeck from the Institute of Geography, University of Bern for the conception and realization of cartographic Fig. 1 and the Swiss Federal Statistical Office for the data on the general Bernese population in 1997. We thank Mrs Karin Winterberger, Mrs Murielle Groux, Mrs Nicole Laporte, Mrs Monika Moser and Mr Fernand Ineichen for their active cooperation in the logistic process of organizing, mailing, sorting and chemical analyzing.

\section{References}

1 Als C, Gerber H, Brander L, Lüscher D, Lauber K \& Rösler H. Iodine supply varies over time in an affluent society such as Switzerland. Experimental and Clinical Endocrinology 102 (Suppl 1) 1994189.

2 Als C, Lauber K, Brander L, Lüscher D \& Rösler H. The instability of dietary iodine supply over time in an affluent society. Experientia (Basel) 61995 623-633.

3 Bürgi H, Supersaxo Z \& Selz B. Iodine deficiency diseases in Switzerland one hundred years after Theodor Kocher's survey: a historical review with some new goitre prevalence data. Acta Endocrinologia 1231990 577-590.

4 von Fellenberg Th. Vorkommen von Jod in der Natur: Zusammenhang zwischen Kropfhäufigkeit und Jodgehalt der Umwelt. Biochemische Zeitung 1521924 148-154.

5 Gerber D. Schilddrüsengewichte und Jodsalzprophylaxe. Schweizer Medizinische Wochenschrift 1101980 2010-2020.

6 Bohnhoff Z. Schilddrüsengewichte und Jodsalzprophylaxe. Schweizerische Medizinische Wochenschrift $1181988244-248$.

7 Bürgi H, Portmann L, Podoba J, Vertongen F \& Srbecky M. Thyroid volumes and urinary iodine in Swiss school children 17 years after improved prophylaxis of iodine deficiency. European Journal of Endocrinology 1401999 104-106.

8 Malone J, Unger J, Delange F, Lagasse R \& Dumont JE. Thyroid consequences of Chernobyl accident in the countries of the European community. Journal of Endocrinological Investigation 14 $1991701-717$.

9 Konno N, Yuri K, Miura K, Kumagai M \& Murakami S. Clinical evaluation of the iodide/creatinine ratio of casual urine samples as an index of daily iodide excretion in a population study. Endocrine Journal 401993 163-169.

10 Dunn JT. Seven deadly sins in confronting endemic iodine deficiency, and how to avoid them. Journal of Clinical Endocrinology and Metabolism 811996 1332-1335.

11 Bourdoux P, Ermans AM, Mukalay wa Mukalay A, Filetti S \& Vigneri R. Iodine-induced thyrotoxicosis in Kivu, Zaire. Lancet $\mathbf{3 4 7} 1996552-553$.

12 Delange F, Benker G, Caron Ph., Eber O, Ott W \& Peter F et al. Thyroid volume and urinary iodine in European schoolchildren standardization of values for assessment of iodine deficiency. European Journal of Endocrinology 1361997 180-187.

13 Als C, Lüscher D, Gerber H, Brander L, Lauber K \& Rösler H. Warum besteht erneut und noch immer Jodmangel in der Region Bern? Schweizerische Medizinische Wochenschrift 1271997 18-22.

14 Truong TH, Gerber H, Haenel A \& Bürgi H. Jodversorgung in verschiedenen Lebensphasen und sonographische Schilddrüsenvolumina bei Schulkindern in einer Gegend der Schweiz. Schweizerische Medizinische Wochenschrift 1271997 715-721.

15 Solca B, Jaeggi-Groisman SE, Saglini V \& Gerber H. Iodine supply in different geographical areas of Switzerland: comparison between rural and urban populations in the Berne and the Ticino regions. European Journal of Clinical Nutrition 531999 754-755.

16 Brander L, Als C, Buess H, Haldimann, F, Harder M, Hänggi, W et al. Iodine supply during pregnancy in an area of unstable dietary iodine intake in Switzerland. Medical dissertation, University of Bern, 1997.

17 Anon. Swiss confederate population census. In Eidgenössische Volkszählung 1990, Haushalte und Familien, Geographische Tabellen. Bundesamt für Statistik, Bern 1993, Tables 7.003-00:108. Federal Administration.

18 Pfister C \& Egli H-R. Bevölkerungsdichte 1990. In Historischstatistischer Atlas des Kantons Bern 1750-1995, pp 48-49. Eds/ publ. Historischer Verein des Kantons Bern. LICORNE (Murten, Switzerland), 1998.

19 Zeyer A. Männliche und weibliche Gesundheit. Unterschiede aus biologischer und lebensgeschichtlicher Perspektive. Neue Zürcher Zeitung 157 10 July 199991.

20 Als C, Helbling A, Peter K, Haldimann M, Zimmerli B \& Gerber H. Urinary iodine concentration follows a circadian rhythm: a study with 3023 spot samples in adults and children. Journal of Clinical Endocrinology and Metabolism 852000 1367-1369.

21 Wüthrich C, Jaeggi-Groisman SE \& Gerber H. Comparison of two methods for the detection of urinary iodine used in epidemiological studies. Clinical Chemistry and Laboratory Medicine 382000.

22 Haldimann M, Zimmerli B, Als C \& Gerber H. Direct determination of urinary iodine by inductively coupled plasma mass spectrometry 
using isotope dilution with iodine-129. Clinical Chemistry $\mathbf{4 4}$ 1998 817-824.

23 Rasmussen LB, Ovesen L \& Christiansen E. Day-to-day and withinday variation in urinary iodine excretion. European Journal of Clinical Nutrition 531999 401-407.

24 Delange F. Requirements of iodine in humans. In Iodine Deficiency in Europe. A Continuing Concern, pp 5-16. Eds F Delange, JT Dunn \& D Glinoer. New York: Plenum, 1993.

25 Als C, Minder C, Willems D, Van Thi HV, Gerber H \& Bourdoux. To measure or not to measure both urinary creatinine and volume in the assessment of ioduria? That is the question. Journal of Endocrinological Investigation 20199730.

26 Sieber R, Badertscher R, Bütikofer U \& Nick B. Composition of Swiss pasteurised and ultra-high-temperature-treated milk. Mitteilungen aus Lebensmitteluntersuchung und Hygiene $901999135-$ 144.

27 Wenlock RW, Buss DH, Moxon RE \& Bunton NG. Trace nutrients 4: iodine in British food. British Journal of Nutrition 471982381 390.

28 Glinoer D. The thyroid in pregnancy: a European perspective. Thyroid Today XVIII 1995 1-11.

29 Glinoer D, De Nayer P, Delange F, Lemone M, Toppet V, Spehl M et al. A randomized trial for the treatment of mild iodine deficiency during pregnancy: maternal and neonatal effects. Journal of Clinical Endocrinology and Metabolism 801995 258-269.

30 Aghini-Lombardi F, Pinchera A, Antonangeli L, Rago T, Fenzi GF \& Nanni P et al. Iodized salt prophylaxis of endemic goiter: an experience in Toscana (Italy). Acta Endocrinologica 1291993 497-500.

31 Bürgi U, Gerber H \& Studer H. Goitrogenesis in iodine deficiency. In Iodine Deficiency in Europe. A Continuing Concern, pp 61-67. Eds F Delange, J Dunn \& D Glinoer. New York: Plenum, 1993.

32 Peter HJ, Bürgi U \& Gerber H. Pathogenesis of nontoxic diffuse and nodular goiter. In Werner's and Ingbar's The Thyroid edn 7, ch 78 , pp 890-895. Eds LE Braverman \& R Utiger. Philadelphia: JB Lippincott, 1996.
33 Als C, Listewnik M, Rösler H \& Bartkowiak E. Immunogenic and non-immunogenic hyperthyroidism. Recent trends in Prealpine Switzerland and in Coastal Poland. Nuclear Medicine $34199592-$ 99.

34 Bürgi H, Kohler M \& Morselli B. Thyrotoxicosis incidence in Switzerland and benefit of improved iodine supply (Letter). Lancet 35219981034.

35 Mostbeck A, Galvan G, Bauer P, Eber O, Atefie K \& Dam K et al. The incidence of hyperthyroidism in Austria from 1987 to 1995 before and after an increase in salt iodization in 1990. European Journal of Nuclear Medicine 241998 367-374.

36 Mordasini C, Abetel G, Lauterburg H, Ludi P, Perrenoud JP \& Schmit $\mathrm{H}$ et al. Untersuchungen zum Kochsalzkonsum der schweizerischen Bevölkerung. Schweizerische Medizinische Wochenschrift 1141984 1924-1929.

37 Ylli A, Bernstein M, Curtain F \& Morabia A. Statut socioéconomique et alimentation: enquête du bus santé 2000, 19931994. In Quatrième rapport sur la nutrition en Suisse, pp 210-224. Eds Office Fédéral de la Santé Publique. Swiss Federal Administration: Bern, 1998.

38 Zimmermann MB, Hess S, Zeder C \& Hurrell RF. Urinary iodine concentrations in Swiss schoolchildren from the Zurich area and the Engadine valley. Schweizerische Medizinische Wochenschrift 128 $1998770-774$.

39 Fleury Y, van Melle G, Woringer V, Temler E, Gaillard RC \& Portmann L. Iodine nutrition and prevalence of goiter in adolescents in the canton of Vaud. Schweizerische Medizinische Wochenschrift 1291999 1831-1838.

40 Deiss M. Jodversorgung in der Schweiz. Können Ernährungsempfehlungen zur Verbesserung beitragen? Dissertation, December 1998. School of Nutritional Counseling, University of Bern.

Received 10 May 2000

Accepted 24 July 2000 